\title{
Perbedaan Tekanan Darah, Laju Jantung dan Rate Pressure Product (RPP) Pada Pemberian Lidokain 1,5 Mg/Kgbb Intravena Sebelum Intubasi Dibandingkan Pemasangan Laryngeal Mask Airway (LMA)
}

\author{
The Difference In Blood Pressure, Heart Rate, And Rate Pressure Product \\ (RPP) In The Administration Of Lidocaine $1.5 \mathrm{Mg} / \mathrm{Kg}$ Intravenously Before \\ Intubation Compared To Laryngeal Mask Airway (LMA) Insertion
}

\author{
Derajad Bayu Atmawan*, Yulia W Villyastuti*, Mohamad Sofyan Harahap* \\ *Bagian Anestesiologi dan Terapi Intensif FK Undip/ RSUP dr. Kariadi, Semarang
}

\begin{abstract}
Background: Laryngoscopic intubation is commonly did in anesthesia practice to secure the airway. But it associated with marked increases in heart rate, and systemic blood pressure. These hemodynamic changes can be attenuated with antiarrythmic drug such as lidocaine. The use of the LMA has been widely recognized less cardiovascular impact than intubation.

Objective: To determine differences in blood pressure, heart rate and RPP in the administration of intravenous lidocaine prior to intubation laryngoscopy compared with LMA insertion

Methods: 38 ASA I-II patients undergoing elective surgery were divided into 2 groups. After induction of general anesthesia, Group 1 was given lidocaine $1.5 \mathrm{mg} / \mathrm{kg}$ and performed laryngoscopy intubation. Group 2 performed the insertion of LMA. Systolic (SBP), diastolic (DBP), mean (MAP) blood pressures, heart rate (HR) and Rate Pressure Product (RPP) were recorded before the induction of anesthesia, before treatment (intubation or insertion of LMA) and after treatment at minute $1^{\text {st }}, 2^{\text {nd }}, 5^{\text {th }}$ and $10^{\text {th }}$.

Results: No significant differences between groups include age, BMI, gender and blood pressure before induction. Both groups has significantly increase in blood pressure, heart rate and RPP at minute $1^{\text {st }}$ and $2^{\text {nd }}$. These increases are significantly greater in Group 1.

Conclusion: LMA insertion contribute less cardiovascular response compared to laryngoscopic intubation administered with lidocaine $1,5 \mathrm{mg} / \mathrm{kg}$ intravenously before.
\end{abstract}

Keywords: lidocaine, intubation, blood pressure, heart rate, RPP, LMA

\section{ABSTRAK}

Latar belakang: Intubasi endotrakeal merupakan tindakan pengelolaan jalan nafas yang sering dilakukan di bidang anestesiologi. Akan tetapi tindakan ini dapat menyebabkan gejolak kardiovaskuler berupa perubahan tekanan darah, laju jantung dan disritmia. Terdapat berbagai teknik dan pengunaan obat untuk mengurangi kondisi tersebut, diantaranya memberikan lidokain intravena sebelum intubasi.

Tujuan: Mengetahui perbedaan tekanan darah, laju jantung dan RPP pada pemberian lidokain intravena sebelum laringoskopi intubasi dibandingkan dengan 
pemasangan LMA

Metode: 36 pasien ASA I-II yang menjalani operasi elektif dalam anestesi umum dibagi menjadi 2 kelompok. Kelompok 1 diberi lidokain $1,5 \mathrm{mg} / \mathrm{kgBB}$ dan dilakukan laringoskopi intubasi. Kelompok 2 dilakukan pemasangan LMA. Dilakukan pencatatan tekana darah sistolik (TDS), diastolik (TDD), tekanan arteri rerata (TAR), laju jantung (LJ) dan Rate Pressure Product (RPP) sebelum induksi anestesi, sebelum perlakuan (intubasi atau pemasangan LMA) dan setelah perlakuan pada menit ke-1, ke-2, ke-5 dan ke-10.

Hasil: Tidak ada perbedaan signifikan antar kelompok meliputi usia, BMI, jenis kelamin maupun tekanan darah sebelum induksi. Peningkatan tekanan darah dan laju jantung pada kelompok 1 lebih tinggi dibandingkan kelompok 2, dengan nilai tertinggi

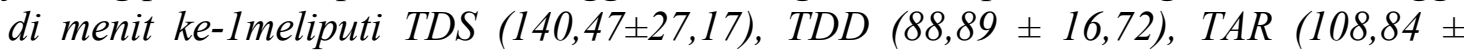
18,84), LJ (90,37 $\pm 11,96)$ dan RPP $(12806,89 \pm 3410,49)$. Perbedaan ini bermakna dibandingkan kelompok 1 pada menit ke-1 dan ke-2 setelah perlakuan.

Simpulan: Terdapat peningkatan bermakna tekanan darah, laju jantung dan RPP pada tindakan laringoskopi intubasi yang diberi lidokain $1,5 \mathrm{mg} / \mathrm{kgBB}$ intravena dibandingkan pemasangan LMA

Kata kunci: lidokain, intubasi, tekanan darah, laju jantung, RPP, LMA

\section{PENDAHULUAN}

Pengelolaan jalan nafas merupakan tindakan yang penting dalam bidang anestesiologi, baik untuk operasi maupun pemberian ventilasi mekanik. Pemasangan pipa ET, atau biasa disebut intubasi, merupakan tindakan pengamanan dan pemeliharaan jalan nafas paling paten. Intubasi paling banyak dilakukan menggunakan teknik laringoskopi. Namun tindakan ini bukan tanpa risiko. Laringoskopi dan intubasi ini selain dapat menyebabkan trauma, juga dapat menimbulkan gejolak kardiovaskuler berupa peningkatan tekanan darah, peningkatan laju jantung dan disritmia. ${ }^{2,3}$ Hal ini disebabkan oleh respon aktivitas simpatis dan pelepasan katekolamin akibat rangsangan pada daerah laring, trakea, karina dan bronkus. ${ }^{4,5,6}$ Pada orang sehat respon ini sebagian besar dapat ditoleransi, tetapi berbahaya bagi penderita dengan faktor risiko seperti hipertensi, penyakit jantung koroner, kelainan serebrovaskuler dan aneurisma intrakranial. ${ }^{7,8}$ Perubahan hemodinamik pada pasien dengan gangguan koroner dan atau iskemia miokard menimbulkan konsekuensi yang berat, terutama pada usia lanjut dan pasien dengan kelainan vaskuler. Pencegahan perubahan hemodinamik pada saat laringoskopi dan intubasi dapat membantu menghindari iskemia. $^{9}$

Berbagai penelitian dilakukan untuk mengetahui metode pencegahan gejolak hemodinamik pada saat laringoskopi dan intubasi. Diantaranya yaitu penggunaan berbagai teknik intubasi, pemilihan peralatan jalan nafas serta penambahan obat sebelum intubasi menggunakan 
lidokain, fentanyl, remifentanil, alfentanil, penyekat beta, nifedipin, klonidin dan diltiazem. ${ }^{1,9,10 \text {, }}$

Lidokain merupakan obat anestesi golongan amida, selain sebagai obat anestesi lokal lidokain juga digunakan sebagai obat antiaritmia kelas IB, mekanisme kerjanya menghambat laju depolarisasi dengan mencegah atau mengurangi permeabilitas natrium. ${ }^{11}$ Injeksi lidokain intravena sebelum intubasi menurunkan respon terhadap manipulasi jalan nafas, sehingga mengurangi peningkatan laju jantung dan tekanan darah. ${ }^{12}$

Rate Pressure Product (RPP) merupakan hasil perkalian antara tekanan darah sistolik dan laju jantung. Nilai RPP merupakan indikator untuk mengambarkan kebutuhan oksigen jantung yang telah luas digunakan secara klinis. Penelitian yang dilakukan menggunakan pencitraan radiologis menunjukkan RPP berkaitan dengan perfusi miokard. ${ }^{13}$

Penelitian yang dilakukan oleh Mohzeni dkk menyatakan bahwa pemberian lidokain $\quad 1,5 \quad \mathrm{mg} / \mathrm{kgBB} \quad$ sebelum laringoskopi dan intubasi lebih efektif mencegah perubahan hemodinamik dibandingkan pemberian nifedipin sublingual. ${ }^{9}$ Sukron dkk menyatakan pemberian lidokain $1,5 \mathrm{mg} / \mathrm{kgBB}$ intravena sebelum tindakan laringoskopi dan intubasi dapat mengurangi gejolak kardiovaskuler. ${ }^{14}$

Penggunaan Laryngeal Mask Airway
(LMA) semakin meluas dewasa ini. Hal ini karena penggunaan LMA memiliki berbagai keuntungan diantaranya mudah dan cepat memasukkan, tanpa laringoskopi, respon hemodinamik lebih stabil dibandingkan pemasangan pipa ET, serta cedera trakea yang minimal karena posisinya berada di superior laring. ${ }^{15,16}$ Meskipun demikian, pemasangan LMA bisa menimbulkan perubahan respon hemodinamik berupa peningkatan tekanan darah dan laju jantung, akan tetapi peningkatan ini lebih kecil dibandingkan setelah laringoskopi dan intubasi pipa ET. ${ }^{17,18,19}$

Berbagai data penelitian diatas menyebabkan berkembangnya pemikiran untuk membandingkan respon tekanan darah, laju jantung dan RPP pemberian lidokain intravena sebelum intubasi dibandingkan pemasangan LMA.

\section{METODE}

Penelitian eksperimental ini dilakukan di Instalasi Bedah Sentral RSUP Dr. Kariadi Semarang. Sampling menggunakan metode consecutive meliputi 38 pasien status fisik sesuai kriteria ASA (American Society of Anesthesiologists) I dan II, yang menjalani operasi elektif dalam anestesi umum selain bedah jantung dan sesar, tanpa adanya kelainan jalan nafas, hipertensi, penyakit jantung, penyakit hepar maupun kelainan ginjal. Sampel dibagi menjadi 2 kelompok masingmasing 19 orang.

Terhadap kedua kelompok dilakukan 
induksi anestesi umum menggunakan fentanyl $1 \mu \mathrm{g} / \mathrm{kg}$, propofol $2 \mathrm{mg} / \mathrm{kgBB}$, dan vecuronium bromide $0,1 \mathrm{mg} / \mathrm{kgBB}$. Untuk kelompok 1 ditambah lidokain $1,5 \mathrm{mg} / \mathrm{kgBB}$ intravena. Setelah onset pelumpuh tercapai, kelompok 1 dilakukan laringoskopi intubasi sedangkan kelompok 2 dilakukan pemasangan LMA.

Tekanan darah sistolik (TDS), tekanan darah diastolik (TDD), tekanan arteri rerata (TAR), laju jantung (LJ) dan Rate Pressure Product (RPP) dicatat pada saat sebelum dilakukan induksi, setelah dilakukan induksi/ sebelum perlakuan, kemudian setelah perlakukan pada menit ke 1, 2, 5 dan 10. Pengukuran menggunakan peralatan monitoring noninvasif Siemens ${ }^{\mathrm{TM}}$ SC 7000.

Data dicatat dalam formulir dan diolah menggunakan perangkat lunak SPSS. Penelitian ini tidak terkait konflik kepentingan dengan pihak manapun.

\section{HASIL}

Telah dilakukan penelitian terhadap 38 pasien yang menjalani operasi elektif dengan anestesi umum di Instalasi Bedah Sentral RSUP dr.Kariadi Semarang sesuai kriteria inklusi dan eksklusi. Pasien dibagi menjadi 2 kelompok, masing-masing 19 orang. Kelompok 1 mendapatkan injeksi lidokain $1,5 \mathrm{mg} / \mathrm{kgbb}$ intravena sebelum intubasi ET. Kelompok 2 dilakukan pemasangan LMA. Tidak ada sampel yang dikeluarkan dari penelitian ini.
Dari seluruh sampel didapatkan jenis kelamin laki-laki 15 orang dan perempuan 23 orang, sebagaimana pada Tabel 1. Data analisis statistik menunjukkan bahwa sampel antara kedua kelompok tidak berbeda secara bermakna dalam hal jenis kelamin, usia dan BMI.

Pencatatan dampak perlakuan meliputi: tekanan darah sistolik (TDS), tekanan darah diastolik (TDD), tekanan arteri rerata (TAR), laju jantung (LJ) dan rate pressure product (RPP) pada saat sebelum induksi anestesi, sebelum tindakan intubasi atau LMA, setelah intubasi pada menit ke-1, 2, 5 serta 10 . Data pencatatan tercantum pada Tabel 2.

Tekanan darah sistolik (TDS) sebelum induksi anestesi pada kelompok 1 sebesar $127,47 \pm 10,79 \mathrm{mmHg}$ sedangkan pada kelompok 2 sebesar $122,42 \pm 13,80 \mathrm{mmHg}$. Nilai tersebut tidak menunjukkan perbedaan bermakna $(p=0,217)$. Setelah dilakukan induksi anestesi terdapat penurunan TDS yang bermakna $(p=0,045)$. Nilai TDS pada masing-masing kelompok naik secara bermakna pada menit ke-1 dan 2, akan tetapi bila dibandingkan antar kelompok kenaikan ini lebih besar secara bermakna pada kelompok 1 .

Tekanan darah diastolik (TDD) sebelum induksi tidak berbeda secara bermakna antara kelompok 1 dan $2 \quad(p=0,277)$. Nilai TDD pada masing-masing kelompok naik secara bermakna pada menit ke-1 dan 2, akan tetapi bila dibandingkan antar kelompok kenaikan 
ini lebih besar secara bermakna pada kelompok $1(\mathrm{p}=0,019)$.

Tekanan arteri rerata (TAR) pada kedua kelompok sebelum induksi anestesi tidak berbeda secara bermakna. Pada menit ke-1 dan 2, TAR pada masingmasing kelompok naik secara bermakna. Kenaikan ini lebih besar secara bermakna pada kelompok 1 $(p=0,014)$.

Laju jantung (LJ) kedua kelompok sebelum induksi anestesi tidak berbeda secara bermakna. Peningkatan laju jantung terjadi pada masing-masing kelompok setelah perlakuan pada menit ke-1 dan 2. Peningkatan tersebut lebih besar secara bermakna pada kelompok 1 di menit ke-1 $(\mathrm{p}=0,02)$ dan menit ke-2 $(\mathrm{p}=0,049)$.

Rate Pressure Product kedua kelompok sebelum induksi anestesi tidak berbeda secara bermakna. Setelah perlakuan, RPP masing-masing kelompok meningkat secara bermakna pada menit ke-1 dan 2. Nilai RPP lebih tinggi pada kelompok $1(\mathrm{p}=0,003)$ dan menit ke-2 $(\mathrm{p}=0,028)$

Dari seluruh sampel pasien, tidak ditemukan kejadian desaturasi $\mathrm{SpO}_{2}<$ 93\% yang diukur dari pulse oksimetri. Tidak didapatkan komplikasi trauma jalan nafas berupa cedera gigi maupun mukosa mulut.

\section{PEMBAHASAN}

Intubasi endotrakea merupakan tindakan pemasangan alat jalan nafas yang paling paten untuk operasi maupun ventilasi mekanik. Namun, tindakan ini bukanlah tanpa risiko. Salah satu komplikasinya yaitu adanya gejolak kardiovaskuler berupa peningkatan tekanan darah dan laju jantung serta naiknya kebutuhan oksigen jantung.

Dari penelitian sebelumnya mengemukakan bahwa pemasangan LMA menimbulkan gejolak kardiovaskuler dan pelepasan katekolamin yang lebih rendah dibandingkan intubasi endotrakea. namun belum pernah ada yang melakukan penelitian untuk membandingkan responnya apabila intubasi endotrakea dilakukan setelah injeksi lidokain intravena.

Pemberian lidokain intravena sebelum intubasi endotrakea dilakukan dengan harapan untuk mengurangi gejolak kardiovaskuler akibat intubasi. Penelitian ini membandingkan pemberian lidokain $1,5 \mathrm{mg} / \mathrm{kg}$ intravena sebelum intubasi endotrakea dibandingkan dengan pemasangan LMA, terhadap gejolak kardiovaskuler ditinjau dari perubahan tekanan darah, laju jantung dan Rate Pressure Product (RPP).

Intubasi terkait dengan respon kardiovaskuler berupa peningkatan tekanan darah dan laju jantung. Selain itu juga dapat terjadi disritmia, refleks batuk, peningkatan tekanan intrakranial dan intraokuler. Tanpa adanya obat dan teknik khusus untuk mengurangi gejolak kardivaskuler tersebut, laju jantung 
Tabel 1. Karakteristik sampel

\begin{tabular}{llcccc}
\hline \multirow{2}{*}{ Variabel } & \multicolumn{2}{c}{ Kelompok 1 } & \multicolumn{2}{c}{ Kelompok 2 } & \multirow{2}{*}{ P } \\
\cline { 2 - 4 } & $\mathrm{L}$ & $\mathrm{P}$ & $\mathrm{L}$ & $\mathrm{P}$ & \\
\hline Jenis kelamin & 7 & 12 & 8 & 11 & $0,740^{\mathrm{a}}$ \\
Usia & $45 \pm 9,7$ & $40,63 \pm 10,27$ & $0,186^{\mathrm{b}}$ \\
BMI & $22,64 \pm 2,82$ & $21,84 \pm 2,29$ & $0,345^{\mathrm{b}}$ \\
\hline
\end{tabular}

Keterangan: $\mathrm{L}=$ laki-laki, $\mathrm{P}=$ perempuan, $\mathrm{BMI}=$ Body Mass Index, $\mathrm{p}=$ derajat kemaknaan, ${ }^{\mathrm{a}}=$ Chi-Square tests, ${ }^{\mathrm{b}}=$ Independent Sample T-test

dapat meningkat hingga $26-66 \%$, dan tekanan darah sistolik meningkat hingga $36-45 \% .^{20}$

Perubahan hemodinamik akibat laringoskopi intubasi dipengaruhi oleh kombinasi efek obat yang digunakan saat induksi anestesi, penggunaan pelumpuh otot, tindakan laringoskopi serta saat dilakukan intubasi. Hasil penelitian ini menunjukkan setelah dilakukan pemberian obat induksi, tekanan darah dan laju jantung menurun. Hal ini karena obat induksi anestesi menurunkan aktivitas simpatis dan menurunkan tekanan vaskuler perifer. ${ }^{21}$

Sebelum induksi anestesi tekanan darah sistolik (TDS) pada kelompok 1 sebesar $127,47 \pm 10,79 \mathrm{mmHg}$, TDS kelompok 2 sebesar 122,42 $\pm 13,80 \mathrm{mmHg}$ perbedaan ini tidak bermakna secara statistik $(\mathrm{p}=0,127)$. Namun setelah dilakukan induksi anestesi menggunakan propofol $2 \mathrm{mg} / \mathrm{kg}$ dan vecuronium bromide 0,1 $\mathrm{mg} / \mathrm{kg}$ serta fentanyl $1 \mu \mathrm{g} / \mathrm{kg}$ terjadi penurunan pada kelompok 1 yaitu $112,74 \pm 11,53 \mathrm{mmHg}$ dan kelompok 2 sebesar $104 \pm 14,29 \mathrm{mmHg}$. Perbedaan ini bermakna dengan uji T-test $\mathrm{p}=0,045$.
Perbedaan penurunan tekanan darah ini dimungkinkan terjadi karena perbedaan respon antara satu individu dengan lainnya meskipun sudah dilakukan pembatasan usia dan BMI, serta membuat kriteria eksklusi berupa kelainan jantung, hati dan ginjal. Uji statistik sebelumnya pada sampel juga tidak didapatkan perbedaan bermakna dalam hal usia, BMI maupun jenis kelamin. Kondisi ini juga terjadi pada pengamatan tekanan darah diastolik.

Rerata usia pada kelompok 1 (intubasi) lebih tua (45 $\pm 9,7$ tahun) dibandingkan kelompok 2 (40,63 $\pm 10,27$ tahun). Peningkatan usia merupakan salah satu penentu penurunan dosis propofol yg dibutuhkan untuk induksi, dan bisa meningkatkan efek hemodinamik propofol. Cleane GJ, dkk menyatakan bahwa umur mempengaruhi dosis

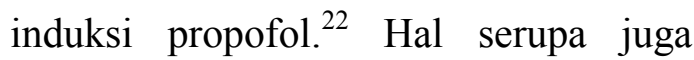
disampaikan Adachi dkk dan Kazama dkk bahwa peningkatan umur menurunkan kebutuhan dosis propofol untuk induksi berkaitan dengan respon farmakodinamik dan farmakokinetik terhadap usia. ${ }^{23,24}$ Akan tetapi pada penelitian ini, penurunan TDS lebih tajam pada kelompok yang lebih muda 
Tabel 2. Nilai tekanan darah, laju jantung dan RPP dari hasil penelitian.

\begin{tabular}{|c|c|c|c|}
\hline Parameter & Kelompok 1 & Kelompok 2 & $\mathrm{P}$ \\
\hline \multicolumn{4}{|l|}{ TDS (mmHg) } \\
\hline Sebelum induksi & $127,47 \pm 10,79$ & $122,42 \pm 13,80$ & 0,217 \\
\hline Sebelum perlakuan & $112,74 \pm 11,53$ & $104 \pm 14,29$ & 0,045 \\
\hline \multicolumn{4}{|l|}{ Setelah perlakuan } \\
\hline Menit ke-1 & $140,47 \pm 27,17 *$ & $119,58 \pm 19,09 *$ & 0,009 \\
\hline Menit ke-2 & $133,53 \pm 27,71 *$ & $120,11 \pm 25,29 *$ & 0,128 \\
\hline Menit ke-5 & $118,84 \pm 22,64$ & $111,58 \pm 20,86$ & 0,311 \\
\hline Menit ke-10 & $112,21 \pm 17,16$ & $106,53 \pm 15,67$ & 0,293 \\
\hline \multicolumn{4}{|l|}{ TDD (mmHg) } \\
\hline Sebelum induksi & $74,21 \pm 6,13$ & $71,37 \pm 9,40$ & 0,277 \\
\hline Sebelum perlakuan & $69,53 \pm 9,46$ & $60,58 \pm 9,95$ & 0,007 \\
\hline \multicolumn{4}{|l|}{ Setelah perlakuan } \\
\hline Menit ke-1 & $88,89 \pm 16,72 *$ & $74,05 \pm 20,27 *$ & 0,019 \\
\hline Menit ke-2 & $79,21 \pm 15,72 *$ & $71,47 \pm 14,40^{*}$ & 0,122 \\
\hline Menit ke-5 & $71,53 \pm 12,88$ & $63,58 \pm 12,61$ & 0,063 \\
\hline Menit ke-10 & $68,74 \pm 11,14$ & $61,37 \pm 10,04$ & 0,039 \\
\hline \multicolumn{4}{|l|}{ TAR (mmHg) } \\
\hline Sebelum induksi & $89,74 \pm 7,87$ & $87,05 \pm 11,48$ & 0,406 \\
\hline Sebelum perlakuan & $83,47 \pm 11,21$ & $76,11 \pm 11,35$ & 0,052 \\
\hline \multicolumn{4}{|l|}{ Setelah perlakuan } \\
\hline Menit ke-1 & $108,84 \pm 18,84 *$ & $91,95 \pm 21,29 *$ & 0,014 \\
\hline Menit ke-2 & $97,47 \pm 22,25^{*}$ & $87,74 \pm 14,93 *$ & 0,122 \\
\hline Menit ke-5 & $86,42 \pm 15,26$ & $81,47 \pm 12,71$ & 0,285 \\
\hline Menit ke-10 & $85,74 \pm 15,18$ & $78,89 \pm 10,67$ & 0,117 \\
\hline \multicolumn{4}{|c|}{ Laju jantung (permenit) } \\
\hline Sebelum induksi & $82,47 \pm 6,63$ & $81,47 \pm 11,15$ & 0,739 \\
\hline Sebelum perlakuan & $77,79 \pm 11,93$ & $78,53 \pm 13,85$ & 0,862 \\
\hline \multicolumn{4}{|l|}{ Setelah perlakuan } \\
\hline Menit ke-1 & $90,37 \pm 11,96^{*}$ & $81,26 \pm 11,03 *$ & 0,020 \\
\hline Menit ke-2 & $87,00 \pm 15,34^{*}$ & $77,95 \pm 11,79 *$ & 0,049 \\
\hline Menit ke-5 & $80,68 \pm 15,89$ & $74,53 \pm 13,37$ & 0,204 \\
\hline Menit ke-10 & $72,95 \pm 14,36$ & $70,47 \pm 13,97$ & 0,594 \\
\hline \multicolumn{4}{|l|}{$R P P$} \\
\hline Sebelum induksi & $10541,68 \pm 1484,62$ & $9953,58 \pm 1681,15$ & 0,621 \\
\hline Sebelum perlakuan & $8819,84 \pm 1881,68$ & $8125,00 \pm 1700,14$ & 0,240 \\
\hline \multicolumn{4}{|l|}{ Setelah perlakuan } \\
\hline Menit ke-1 & $12806,89 \pm 3410,49 *$ & $9792,21 \pm 2456,92^{*}$ & 0,003 \\
\hline Menit ke-2 & $11812 \pm 3852,15^{*}$ & $9384,00 \pm 2527,82^{*}$ & 0,028 \\
\hline Menit ke-5 & $9780,47 \pm 3345,83$ & $8264,79 \pm 1876,71$ & 0,094 \\
\hline Menit ke-10 & $8267,53 \pm 2430,75$ & $7503,79 \pm 1951,18$ & 0,298 \\
\hline
\end{tabular}

Keterangan:

TDS: tekanan darah sistolik,

TDD: tekanan darah diastolik,

TAR: tekanan arteri rerata,

RPP: rate pressure product,

kelompok 1: dilakukan injeksi lidokain $1,5 \mathrm{mg} / \mathrm{kgbb}$ dan laringoskopi intubasi endotrakea,

kelompok 2: dilakukan pemasangan LMA

*: dibandingkan dengan nilai sebelum perlakuan, didapatkan peningkatan yang bermakna $(p<0,05)$ 
(kelompok 2).

Pada kelompok 1 dilakukan pemberian injeksi lidokain 1,5 mg/kgbb intravena pada saat induksi anestesi sebelum intubasi. Dosis tersebut merupakan dosis efektif untuk menurunkan gejolak kardiovaskuler akibat laringoskopi intubasi. Selisih penurunan laju jantung lebih besar pada kelompok ini daripada kelompok 2. Lidokain merupakan obat anestesi lokal yang juga termasuk golongan obat anti disritma kelas IB. Lidokain memperlambat depolarisasi fase 4 dengan jalan menurunkan permeabilitas ion natrium yang normalnya terjadi pada fase ini. ${ }^{11}$

Tam dkk melakukan penelitian untuk menentukan waktu terbaik untuk menyuntikkan lidokain intravena sebelum induksi. Dalam kesimpulannya dinyatakan bahwa penurunan respon hemodinamik paling minimal terjadi pada penyuntikan lidokain 3 menit sebelum intubasi. ${ }^{25}$

Setelah dilakukan tindakan laringoskopi dan intubasi, kelompok 1 menunjukkan peningkatan tekanan darah dan laju jantung yang bermakna dibandingkan kelompok 2.

Penyebab utama respon simpatoadrenal terhadap intubasi endotrakea adalah adanya rangsangan area supraglotik akibat iritasi jaringan yang terkena laringoskop. Rangsangan di area infraglotik berupa sentuhan pipa ET melintasi pita suara dan pengembangan balon memberikan kontribusi lebih rendah. Dengan adanya aktivasi propioseptor, laringoskopi memicu terjadinya hipertensi, takikardi dan peningkatan konsentrasi katekolamin yang sebanding dengan besarnya rangsangan terhadap dasar lidah. ${ }^{26}$

Smith dkk melakukan penelitian mengenai respon hemodinamik setelah dilakukan laringoskopi tanpa intubasi dibandingkan laringoskopi yang diikuti intubasi endotrakea. Pada kelompok laringoskopi tanpa intubasi memberikan gambaran tekanan darah yang meningkat secara nyata tanpa peningkatan laju jantung yang bermakna. Sedangkan pada kelompok yang dilakukan laringoskopi dan dilanjutkan intubasi endotrakea menghasilkan gambaran peningkatan laju jantung yang bermakna dengan respon tekanan darah yang relatif konstan. $^{27}$

Beberapa peneliti yang lain mencoba mencari penyebab respon intubasi dengan menghindari rangsangan faring. Barak dkk mengukur respon intubasi orotrakea menggunakan bilah laringoskop macintosh dibandingkan dengan menggunakan laringoskopi fiberoptik melalui pipa orofaring. Tidak didapatkan perbedaan bermakna antara kedua kelompok perlakuan tersebut. Sedangkan Adachi melakukan penelitian serupa menggunakan laringoskopi fiberoptik, dan menyimpulkan bahwa tindakan intubasi itu sendiri merupakan rangsang utama terjadinya respon kardiovaskuler. $^{23,28}$ 
Tindakan laringoskopi sebelum intubasi dapat dihindari dengan menggunakan Intubating Laryngeal Mask Airway (ILMA). Zhang dkk melakukan penelitian untuk membandingkan respon kardiovaskuler pada kelompok yang dilakukan intubasi melalui ILMA dibandingkan dengan menggunakan laringoskopi direk. Tidak didapatkan perbedaan bermakna respon kardiovaskuler antara dua kelompok perlakuan, akan tetapi pada penelitian ini durasi intubasi menggunakan ILMA lebih lama daripada kelompok laringoskopi direk. ${ }^{29}$

Pada kelompok LMA maupun intubasi terjadi peningkatan tekanan darah dan laju jantung pada menit ke 1 dan 2 . Pengamatan pada menit ke 5 tidak didapatkan peningkatan tekanan darah maupun laju jantung apabila dibandingkan dengan nilai sebelum perlakuan. Hal ini sesuai dengan kepustakaan, dan penelitian lainnya dimana tekanan darah meningkat dalam 5 detik setelah laringoskopi, mencapai puncak dalam 1 sampai 2 menit, dan kembali ke nilai awal dalam waktu 5 menit. $^{30}$ Perubahan hemodinamik ini dapat menyebabkan iskemia miokard, meskipun tidak menimbulkan dampak buruk pada sebagian besar pasien namun harus dihindari pada pasien dengan penyakit jantung. ${ }^{31}$

Sistem kardiovaskuler memiliki autoregulasi otonom terhadap adanya perubahan tekanan darah. Pengendalian cepat, atau disebut immediate control merupakan fungsi utama refleks system saraf otonom. Perubahan tekanan darah dipantau oleh sensor sentral (hipotalamus dan batang otak) serta perifer (baroseptor arteri karotis dan arkus aorta). Bila tekanan darah naik, terjadi pengurangan baroseptor sehingga aliran simpatetik menurun dan tonus vagal meningkat, terjadi hambatan vasokonstriksi sistemik. $^{32}$

RPP merupakan perkalian antara tekanan darah sistolik dan laju jantung. Nilai normalnya kurang dari 12000 . RPP yang meningkat diatas 20000 dikaitkan dengan iskemi miokard dan angina. Peningkatan tekanan darah tanpa peningkatan laju jantung masih lebih baik untuk oksigenasi miokard daripada peningkatan laju jantung bersamaan dengan peningkatan tekanan darah. ${ }^{3}$

RPP pada kelompok 1 lebih tinggi secara bermakna dibandingkan kelompok 2 pada menit ke-1 dan ke-2 setelah perlakuan. Hasil ini sesuai dengan penelitian Hasyim dkk yang mengemukakan bahwa penggunaan lidokain dan diltiazem mengurangi gejolak kardiovaskuler akibat intubasi. ${ }^{33}$ Namun demikian, peningkatan paling besar nilai RPP pada penelitian ini terdapat pada menit pertama setelah perlakuan yaitu sebesar 12806,89 \pm $3410,49 \mathrm{mmHg} / \mathrm{x} / \mathrm{menit}$. Nilai ini masih dibawah batas ambang angina normal yakni diatas $20000 \mathrm{mmHg} / \mathrm{x} /$ menit. $^{34}$

\section{SIMPULAN}

Dari penelitian mengenai penggunaan lidokain $1,5 \mathrm{mg} / \mathrm{kgbb}$ sebelum intubasi 
dibandingkan LMA terhadap tekanan darah, laju jantung dan Rate Pressure Product (RPP) dapat disimpulkan bahwa terdapat peningkatan bermakna terhadap tekanan darah, laju jantung dan RPP setelah tindakan laringoskopi intubasi yang diberi lidokain intravena $1,5 \mathrm{mg} / \mathrm{kg}$ pada menit ke 1 dan 2; terdapat peningkatan bermakna terhadap tekanan darah, laju jantung dan RPP setelah tindakan pemasangan pada menit ke 1 dan 2; dan peningkatan tekanan darah, laju jantung dan RPP pada kelompok intubasi yang diberi lidokain intravena $1,5 \mathrm{mk} / \mathrm{kg}$ lebih tinggi secara bermakna dibandingkan pada kelompok pemasangan LMA

Dapat dilakukan penelitian lebih lanjut guna mengetahui metode untuk menurunkan gejolak kardiovaskuler intubasi menggunakan metode, dosis maupun alat ukur yang berbeda.

\section{DAFTAR PUSTAKA}

1. Airway Management. In: Morgan GE, Mikhail MS, Murray MJ, editors. Clinical Anesthesiology. 4th ed. New York. McGrawHill; 2006: 91-116

2. Hagberg C, Georgi R, Krier C. Complications of managing the airway. Best Practice \& Research Clinical Anaesthesiology. 2005; 19 (4): 641-59

3. Sener EB, Ustun E, Sarihasan B. Hemodynamic responses and upper airway morbidity following tracheal intubation in patients with hypertension: Conventional laryngoscopy versus an intubating laryngeal mask airway. Clinics. 2012;67(1):49-54

4. Siddiqui, Khan FZH. Haemodynamic response to Tracheal Intubation via intubating laryngeal mask airway versus Direct Laryngoscopic Tracheal Intubation. J Pak Med Assoc. January 2007; 57(1): 11-4
5. Simpson GD, Ross MJ, McKeown DW, Ray DC. Tracheal intubation in the critically ill: a multi-centre national study of practice and complications. British Journal of Anaesthesia 2012; 108 (5): 792-9

6. Montazari K, Naghibi K, Hashemi SJ. Comparison of hemodynamic changes after insertion of laryngeal mask airway, face mask and endotracheal intubation. Acta Medica Iranica. 2004; 42(6): 437-40

7. Flemming DC, Orkin Fk, Kirby RR. Hazards of tracheal intubation. In: Nikolous G, Robert RK. Complication in anesthesiology. 2nd ed. Philadelphia: Lippincottraven; 1996: 229-37

8. Shribman AJ, Achola KJ. Cardiovascular and catecholamine responses to laryngoscopy with and without tracheal intubation. Br J Anesth; 1997: 59:295-99

9. Mohseni G, Kolyaei A, Farshchian M, Rezaei M, Ghadami N. Comparison between effects of intravenous lidocaine and sublingual nifedipine on preventing blood pressure increase in laryngoscopy Open Access Journal of Clinical Trials. June 2010; 2: 8992

10.Irgari IP, Nurcahyo WI. Perbedaan respon kardiovaskuler antara fentanil $2 \mu \mathrm{g} / \mathrm{kg}$ dan klonidin $3 \mu \mathrm{g} / \mathrm{kg}$ pada tindakan laringoskopi dan intubasi. [Karya Tulis Ilmiah]. Semarang: Universitas Diponegoro; 2010.

11. Stoelting RK, Hillier SC. Cardiac antidysrhythmic drugs. In: Pharmacology and physiology in anesthetic practice. 2th ed. Philadelphia: Lippincott William \& Wilkins; 2006: 370-86

12. Vivancos GG, Klampt JG, Garcia LV. Effects of 2 mg.kg- 1 of intravenous lidocaine on the latency of two different dose of rocuronium and on the hemodynamic response to orotracheal intubation. Revista Brasileira de Anestesiologia. February 2011; 61(1): 1-12

13. Ansari M, Javadi H, Pourbehi M, Moqharrabi M, Rayzan M, Semnani S, Et al. The Association of rate pressure product (RPP) and myocardial perfusion imaging (MPI) findings: a preliminary study. Perfusion. May 2012; 27(3):207-13

14. Sukron. Perbandingan Efek Magnesium Sulfat $30 \mathrm{mg} / \mathrm{kgBB}$ Intravena dengan Lidokain 1,5 $\mathrm{mg} / \mathrm{kgBB}$ terhadap Respon Kardiovaskuler Akibat Tindakan Laringoskopi dan Intubasi. Semarang: Bagian Anestesi Fakultas Kedokteran Universitas Diponegoro, 2009. 56 pp. Tesis.

15. Brimacombe $\mathrm{J}$. The advantages of the LMA over the tracheal tube or facemask: a meta- 
analysis. Canadian Journal of Anaesthesia. 1995;42:1017-23

16. Yu SH, Beirne OR. Laryngeal Mask Airway have a lower risk of airway complications compared with endotracheal intubation: a systematic review. J Oral Maxillofac Surg 2010; 68:2359-2376

17. Anita N, Shetty, Shinde VS, Chaudari LS. A comparative study of various airway devices as regards ease of insertion and haemodynamic responses. Indian Journal of Anaesthesia, April 2004; 48 (2) : 134-137

18. Shetty AN, Shinde VS, Chaudhari LS. A comparative study of various airway devices as regards ease of insertion and haemodynamic responses. Indian J Anaesth. 2004; 48(2): 134-7

19. Tahir MS, Khan NA, Masood M, Yousaf M, Waris S. A comparison of pressor responses following laryngeal mask airway vs laryngoscopy and endotrakheal tube insertion. Anaesth Pain \& Intensive Care; 12 (1):11-5

20. Mahjoubifar M, Boroojeny SB. Hemodynamic changes during orotracheal intubation with glidescope and direct laryngoscope. Iranian Red Crescent Medical Journal. 2010; 12(4): 406-8

21. Safaee MH, Sepdikar A, Eftekharian HR. Hemodynamic variation following induction and tracheal intubation. MEJ ANESTH, 2007; 19(3): 603-10

22. McCleane GJ, Fogarty DF, Watters CH. Factors that influence the induction dose of propofol. Anaesthesia. Jan 1991;46(1):59-61

23. Adachi YU, watanabe K, Higuchi H, Satoh T. The Determinants of Propofol Induction of Anesthesia Dose. Anesthesia and analgesia. March 2001; 92(3): 656-61

24. Kazama T, Ikeda K, Morita K, Ikeda T, Kikura M, Sato S. Relation between Initial Blood Distribution Volume and Propofol Induction Dose Requirement Anesthesiology. February 2001; 94(2):20510

25. Tam S, Chung F, Campbell M. Intravenous Lidocaine: Optimal Time of Injection before
Tracheal Intubation. Anest Analg. 1987; 66: 1036-8

26. Oczenski W, Krenn H, Dahaba A, Binder M, Irene SK, Jellinek, et al. Hemodynamic and catecholamine stress responses to insertion of combitube, laryngeal mask airway or tracheal intubation. Anesth analg 1999; 88 1389-94

27. Smith P, Smith FJ, Becker PJ. Haemodynamic response to laryngoscopy with and without tracheal intubation. Southern African Journal of Anesthesia and Analgesia 2008; 14(3):23-6

28. Barak M, Ziser A, Greenberg A, Lischinsky S, Rosenberg B. Hemodynamic and catecholamine response to tracheal intubation: direct laryngoscopy compared with fiberoptic intubation. $\mathrm{J}$ Clin Anesth. 2003 Mar;15(2):132-6

29.Zhang GH, Xue FS, Sun HY, Li CW, Sun $\mathrm{HT}, \mathrm{Li} \mathrm{P}$, et al. Comparative study of hemodynamic responses to orotracheal intubation with intubating laryngeal mask airway. Chin Med J (Engl). 2006 Jun 5;119 (11):899-904

30. Mahjoubifar M, Boroojeny SB. Hemodynamic changes during orotracheal intubation with glidescope and direct laryngoscope. Iranian Red Crescent Medical Journal. 2010; 12(4): 406-8

31. Henderson J. Airway management in the adult. In: Miller RD, editor. Anesthesia 7th ed. Philadelphia. Churchil Livingstone; 2010: 1573-1610

32. Cardiovascular physiology and anesthesia. In: Morgan GE, Mikhail MS, Murray MJ, editors. Anesthesiology. 4th ed. New York. McGraw-Hill; 2005: 429-30

33. Hasyim M, Budiono U. Perbandingan efek diltiazem dan lidokain terhadap respon kardiovaskuler pada tindakan laringoskopi dan intubasi. Semarang: Bagian Anestesiologi Fakultas Kedokteran Universitas Diponegoro, 2004. 32 pp. Tesis

34. Nagpal S, Gupta K, Ahuja J. Rate pressure product - a diagnostic tool in determining the cardiovascular risk in postmenopausal women . IJCRR. (2012), [cited February 27, 2013]; 4(20): 134-138 